From Tintype to Twitter: Photography at the Irish Jesuit Archives

Author: Damien Burke

Source: Engaging Sources: The Tradition and Future of Collecting History in the Society of Jesus (Proceedings of the Symposium held at Boston College, June 11-13, 2019)

Edited by: Cristiano Casalini, Emanuele Colombo, and Seth Meehan

ISBN: 978-1-947617-09-4

Published by: Institute of Jesuit Sources

Originally Published: March 1, 2021

https://doi.org/10.51238/ISJS.2019.09

Provided in Open Access by the Institute for Advanced Jesuit Studies at Boston College.

The Institute of Jesuit Sources, specializes in preserving, maintaining, and expanding for scholars around the world important texts and studies in Jesuit history, spirituality, and pedagogy.

Visit our website at https://jesuitsources.bc.edu 


\title{
From Tintype to Twitter: Photography at the Irish Jesuit Archives ${ }^{1}$
}

\author{
DAMIEN BURKE
}

\section{Introduction}

Photographs are fragile objects: physically, they are easily torn, discolored, and mislaid; digitally, the advent of smartphones with the maelstrom of social media means the lifespan of a photograph is fleeting, existing in sharing, before deletion by swiping. Photographs are not passive objects - they tell a story, reflecting the technologies that created them, the photographic object itself, issues of provenance and acquisition, and the role they have played in Jesuit life. ${ }^{2}$ In seeking to promote the medium of photography as a source, equal to the written word in Jesuit studies, the limitations of this article are worth articulating. ${ }^{3}$ I do not delve into the photographic techniques and methods employed by Irish Jesuits. ${ }^{4}$ Likewise, this article reflects a white, Western photographic perspective; a personal working experience of an archivist in one Jesuit province archives. ${ }^{5}$

\footnotetext{
${ }^{1}$ A version of this paper was presented at the International Symposium on Jesuit Studies, Institute for Advanced Jesuit Studies, Boston College, United States, June 17, 2019. I would like to thank those who organized the conference, those who attended, and those who offered feedback.

2 Joanna Sassoon, "Photographic Meaning in the Age of Digital Reproduction," Archives \& Social Studies: A Journal of Interdisciplinary Research 1 (March 2007): 299-317.

${ }^{3}$ Ignatius devised a system of communication "consolidated in the order's Constitutions (1558) and the Formula Scribendi (1580), leaving no Jesuit in doubt as to the number and format of official communications to be written in the course of any given year." Vera Orschel, "'Uniting the Dispersed Members': The 'Annual Letters' of the Irish Jesuits," Studies: An Irish Quarterly Review 103, no. 412 (2014): 402-13. I agree with Jeffrey Muller's assertion that the "Jesuit predilection for the word over images is a separate tradition of historiography that warrants further research." See "Historiography of the Art and Architecture of the Jesuits," in Jesuit Historiography Online, ed. Robert A. Maryks; doi:http://dx.doi.org/10.1163/2468-7723_jho_SIM_192594 (accessed August 3, 2020). See also Markus Friedrich, "Archives as Networks: Geography of Record-Keeping in the Society of Jesus (1540-1773)," Archival Science 10 (2010): 285-98.

4 Ash Anderson touches upon this in reviewing Frank Browne: A Life through the Lens and suggests that the photographs selected "in the book do not tell us much about an inner life-spiritual or otherwise - and it is the outliers, the few innovative exceptions to his familiar pictorial style, that are the most intriguing." Ash Anderson, "Frank Browne: A Life through the Lens, ed. David Davison and Edwin Davison," Journal of Jesuit Studies 2, no. 3 (2015): 535-37, here 537; doi: https://doi.org/10.1163/22141332-00203005-20 (accessed August 3, 2020).

${ }^{5}$ Echoing Pierre Bourdieu's concept of "cultural capital," that certain cultural forms are valued over others and can help or hinder one's social mobility, just as much as income or wealth. Pierre Bourdieu, "The Forms of Capital [1985]," Handbook of Theory of Research for the Sociology of Education (1986): 46-58. I started work at the IJA in 2007, on a one-year cataloging contract, and in 2019 was appointed province archivist.
}

https://doi.org/10.51238/ISJS.2019.09

(C) Institute of Jesuit Sources, 2021 
Jesuit visual culture has been researched most recently by Evonne Levy and Alison Fleming on the early modern period, rooting Ignatian principles in Jesuit architecture, art, and meditational literature. ${ }^{6}$ In the modern era, the medium of photography within the Society of Jesus has yet to be correspondingly investigated. When Jesuit photography is noted, in for example The Cambridge Encyclopedia of the Jesuits (2017), the focus is on the work of individual Jesuits, in this case Jesuits Frank Browne (1880-1960) and Don Doll (1937-). ${ }^{7}$ This lack of broader research is mirrored in blog posts, exhibitions, and publications that concentrate on the work of individual Jesuit photographers, who appear to operate without external influence or encouragement and without imparting their knowledge. ${ }^{8}$ The most wellknown Jesuit photographers, the aforementioned Browne and Doll, as well as John Brosnan (1860-1949) and Eugene Buechel (1874-1954), may have operated as photographic nomads, seeking out opportunities to explore their craft, but they all benefited from some form of familial support, whether genealogical or Jesuit. ${ }^{9}$

\footnotetext{
${ }^{6}$ For further explorations on Jesuit visual culture, see John W. O'Malley, The Jesuits and the Arts: 1540-1773 (Philadelphia: Saint Joseph's University Press, 2006); Evonne Levy, "Early Modern Jesuit Arts and Jesuit Visual Culture," Journal of Jesuit Studies 1, no. 1 (2014): 66-87; and Alison C. Fleming, "Jesuit Visual Culture: Communication, Globalization, and Relationships," Journal of Jesuit Studies 6, no. 2 (2019): 187-95.

${ }^{7}$ Alison C. Fleming, "Photography," in The Cambridge Encyclopedia of the Jesuits, ed. Thomas Worcester (Cambridge: Cambridge University Press, 2017), 612-13.

${ }^{8}$ Over thirty-five publications have been devoted to the photographs of Fr. Browne.

${ }^{9}$ Jesuit John Brosnan, born in New York, was a scientist and official photographer for the Maryland Jesuit province. He provided photographic expertise for the Jesuit scientific community and was an ongoing consultant for Eastman Kodak. John Brosnan, S.J., Photographic Collection at Georgetown University; https://repository.library.georgetown.edu/handle/10822/712493 (accessed August 3, 2020).

Jesuit Eugene Buechel, born in present-day Germany, worked as photographer, linguist, botanist, and missionary among the Lakota (Sioux) of the Pine Ridge and Rosebud Reservations in South Dakota, United States. Material available at Marquette University Special Collections and University Archives; https://www.marquette.edu/library/archives/indians.php (accessed August 3, 2020). Jesuit Francis (Frank) Patrick Mary Browne, born in Cork, Ireland, and worked as chaplain, missioner, and photographer. Frank's uncle, Robert Browne (1844-1935), bishop of Cloyne, is credited with gifting Frank his first camera. In 1950, Frank Browne befriended and taught the basics of photography to the Irish Jesuit John Moore (1927-2018) while Moore was completing a student survey of the bogs of County Laois. Moore later helped Browne when photographing Irish country houses; https://soundcloud.com/jesuits-in-ireland/death-of-a-botanist (accessed August 3, 2019). Jesuit Don Doll, a renowned photographer, who like Browne "came to photography by invitation, in his case from a fellow priest at the St Francis Indian Mission on the Rosebud Sioux Reservation." Maureen O'Connell, "Come and See," America Jesuit Review (February 22, 2016); https://www.americamagazine.org/issue/culture/come-and-see (accessed August 3, 2020). Don Doll, S.J., Collection at Marquette University Special Collections and University Archives; https://www.marquette.edu/library/archives/Mss/DAD/DAD-sc.php (accessed August 3, 2020).
} 


\section{Photography as a Contemplative Practice}

Spirituality and religious belief involve abstract concepts that are often difficult to express in words. Visual material can evoke embodied experience and open opportunities for deeper conversations about what people find sacred. ${ }^{10}$ Tracing its origins back to painting, photography captures the historical along with the picturesque. ${ }^{11}$ Just as there are shifting art trends, photography practices have evolved, from the documentary, to the experimental, and from the box brownie to the iPhone. Photography emotionally connects with people - think of your own family photographs: snapshots frozen in time and place. This emotionality chimes with Ignatius in viewing "his life as a series of dynamic visualizations" and with Dorothea Lange (1895-1965), a photographer known for her Migrant Mother work of 1938, who suggests that photographs are an autobiography of one's life. ${ }^{12}$

In questioning the merits of photography as a contemplative practice, not all Jesuit photography, historic or present day, is of value. Notwithstanding this caveat, it is hard to argue against an "ethics of seeing"13 in the output of Doll, who "found his pathway to God through photography." ${ }^{14} \mathrm{He}$ comments that

as a photographer, I see the world through the lens of who I am and the life I've lived. I can't help but photograph from the life of faith that I've grown into as a priest over the past 49 years. I photograph to tell the stories of people who have no voice. Hopefully I can help others understand and work to change unjust social structures. ${ }^{15}$

Buechel similarly used photography to bear witness, working with the Lakota tribe in South Dakota, and Brosnan's photographs "serve as an incredible exploration of

\footnotetext{
${ }^{10}$ Sarah Dunlop, "Visual Methods in the Study of Religion," discussion paper, University of Kent, 2008, 2; https://www.kent.ac.uk/religionmethods/documents/Visual\%20approaches.pdf (accessed August 3, 2020); Brian Grogan and José Ignacio Tellechea Idígoras, Alone and on Foot (Dublin: Veritas, 2008); Thomas Lucas, S.J., "The Spiritual Exercises and Art," Conversations on Jesuit Higher Education 47, no. 5 (2015): 8-33; https://epublications.marquette.edu/conversations/vol47/iss $1 / 5$ (accessed August 3, 2020).

${ }^{11}$ Eddie O'Donnell, S.J. suggests that Browne acquired composition and artistic techniques when he was sent to study philosophy for three years at Chieri, eighteen miles from Turin, northern Italy, in 1900. He was encouraged by his rector to visit the galleries of Turin and on his holidays visited Rome, Florence, and Venice. See O'Donnell, The Life and Lens of Father Browne (Dublin: Messenger Publications, 2014), 27-29.

${ }^{12}$ Levy, "Early Modern Jesuit Arts and Jesuit Visual Culture," 77.

${ }^{13}$ Susan Sontag, On Photography (London: Penguin, 1997), 3.

${ }^{14}$ Don Doll, S.J., Collection at Marquette University Special Collections and University Archives.

${ }^{15}$ Magis Production website: http://magisproductions.org/magis-productions (accessed August 3, 2020).
} 
the spiritual geography of faith," and "his meticulous compositions, and the lushness of tones, almost invite the viewer into a contemplative state." ${ }^{16}$ Catholic mystic Thomas Merton (1915-68) used photography at the Abbey of Gethsemani, Kentucky, United States, as a contemplative exercise, recording a day's photography as

marvelous, silent, vast spaces around the old buildings. Cold, pure light, and some grand trees. So cold my finger could no longer feel the shutter release. Some marvelous subjects. How the blank side of a frame house can be so completely beautiful I cannot imagine. A completely miraculous achievement of forms. ${ }^{17}$

Merton's fellow convert to Catholicism, the English Jesuit and poet Gerard Manley Hopkins (1844-89), undertook undergraduate pursuits in painting and drawing at the University of Oxford. Gaining an appreciation of the visual techniques of the nineteenth century and influenced by the ideas of John Ruskin (1819-1900), Hopkins was later introduced to the world of photography by his uncle George Giberne (1797-1876), an amateur photographer, draughtsman, and judge. Writing to his sister, Kate, in 1884, Hopkins noted that

a dear old French Father [Jesuit Jacques Mallac (1829-91)], very clever and learned and a great photographer, who at first wanted me to take to photography with him, which indeed in summer would be pleasant enough, finding that once I used to draw, got me to bring him the few remains I still have, cows and horse in chalk done in Wales [...]. ${ }^{18}$

In a counterfactual world, could Hopkins's photographic interests have been developed by Mallac at St. Stephen's Green, so that Hopkins used photography to experiment with the visual and sensual senses, so apparent in his poetry? ${ }^{19}$ In reality, Hopkins was a beleaguered professor of classics at University College, Dublin, from 1884 until his death. Stretching the whatiffery-perhaps photography could

\footnotetext{
${ }^{16}$ Adrian Vaagenes, "A Jesuit and a Kodak," blog, Georgetown University website; https://www.library.georgetown.edu/woodstock/blog/jesuit-and-kodak (accessed August 3, 2020).

${ }^{17}$ Christine Valters Paintner, Eyes of the Heart: Photography as a Christian Contemplative Practice (Notre Dame, IN: Sorin, 2013), 23.

${ }^{18}$ Michael Flecky, Hopkins in Ireland: Pictures and Words (Omaha, NE: Creighton University Press, 2008), 11. Some of the papers of Gerard Manley Hopkins, S.J. are held at the Irish Jesuit Archives (IE IJA/J7).

19 "As kingfishers catch fire, dragonflies draw flame; As tumbled over rim in roundy wells / Stones ring." Opening lines to As Kingfishers Catch Fire, from Gerard Manley Hopkins, Frank Browne, and Jo O'Donovan, Bright Wings, Dappled Things: The Poems of Gerard Manley Hopkins; With Photographs by Francis Browne; Introduction and Commentary by Jo O'Donovan, R.S.M. (Dublin: Messenger Publications, 2018), 43.
} 
have aided Hopkins with his depressive malaise, echoing the transformative effect that photography had on Merton:

What a joy of a thing to work with [...], the camera is the most eager and helpful of all beings, all full of happy suggestions: "Try this! Do it that way!" Reminding me of things I have overlooked and cooperating in the creation of new worlds. So simply. This is a Zen camera. ${ }^{20}$

A twentieth-first-century equivalent occurs at the Irish Jesuit Centre of Spirituality, which provides photography retreats "using the camera or smartphone in a contemplative way [in order to] help see the light of life of [sic] in new ways." 21

\section{Irish Jesuit Photography}

Photography emerged in Ireland simultaneously with its European counterparts in the mid-nineteenth century. Advancements in usage and appreciation of this new medium were facilitated by interest from Anglo-Irish landowners, the establishment of amateur photographic societies, and commercial photographic practices in Irish cities and towns. ${ }^{22}$ Irish Jesuit engagement with photography dates from the 1850s onward, when they first employed photographic studios for portraits. At the foundation of the province in 1860 - Ireland had been a vice-province since 1830 it was manned by 117 Jesuits, "of whom 60 were priests, 28 were scholastics and

${ }^{20}$ Paintner, Eyes of the Heart, 23.

${ }^{21}$ Jesuit Centre of Spirituality, Manresa, Dollymount, Dublin ran a one-day retreat using photography in a contemplative way, July 13, 2019, and a five-day retreat; see https://www.manresa.ie/programmes/one-day-photography-retreat and https://www.maresa.ie/program-mes/seeinglight-life-photography-retreat-7-12-jul (accessed August 3, 2020). See Michael Flecky, S.J., "Our Spirits Matter: Making Photographs as Jesuit Education," Conversations on Jesuit Higher Education 14, no. 8 (1998): 30-33; https://epublications.marquette.edu/conversations/vol14/iss1/8 (accessed August 3, 2020).

${ }^{22}$ For an introduction to the history of Irish photography, see Edward Chandler, Photography in Ireland: The Nineteenth Century (Dublin: Edmund Burke, 2002); Liam Kelly, Photographs and Photography in Irish Local History (Dublin: Four Courts Press, 2008); Justin Carville, Photography and Ireland (London: Reaktion, 2011). Research on religious photography has been conducted by Justin Carville ("Refracted Visions: Street Photography, Humanism, and the Loss of Innocence," in Tracing the Cultural Legacy of Irish Catholicism: From Galway to Cloyne and Beyond, ed. Eamon Maher and Eugene O'Brien [Manchester: Manchester University Press, 2017], 70-88); Fiona Loughnane, National College of Art and Design; and Orla Fitzpatrick, National Museum of Ireland. For an American perspective, see Rachel McBride Lindsey, A Communion of Shadows: Religion and Photography in Nineteenth-Century America (Chapel Hill, NC: University of North Carolina Press, 2017). 
29 brothers" who worked in Jesuit colleges, churches, and parish missions. ${ }^{23}$ Coinciding with this expansion, periods of Jesuit formation (juniorate, philosophy, theology, and tertianship) were often spent in Europe, and in 1865, Australia became the first overseas mission of the Irish Jesuit province. Irish Jesuits used photography for remembrance purposes abroad and sent back portraits and Mass cards to overcome some of the tyranny of distance. ${ }^{24}$ Irish Jesuits also memorialized the deceased by postmortem photography, ${ }^{25}$ for example the Irish Jesuit Christopher Bellew (1818-67).

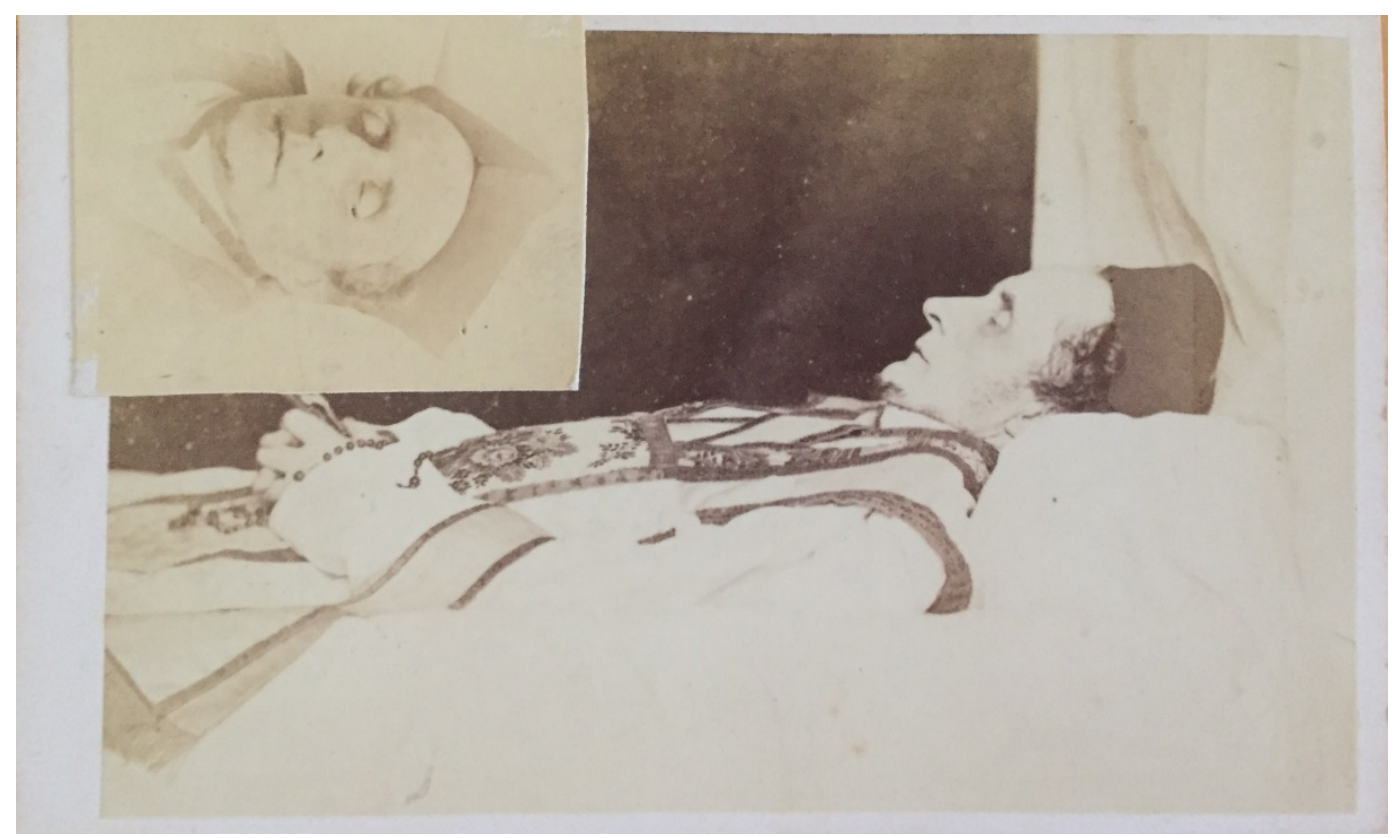

Figure 1. Fr. Christopher Bellew, S.J. (1818-1867). Photograph by Millard \& Robinson, 39 Lower Sackville Street, Dublin. IE IJA/PC/4/10.

By modern sensitivities, deathbed scenes may be considered morbid; however, "photographs produced and viewed in one historical context may be viewed ten,

\footnotetext{
${ }^{23}$ Bruce Bradley, S.J., "Look Back with Thanks: Where Has God Been over the Past 150 Years?," address to the Province Assembly, Gonzaga College, June 11, 2011; https://www.jesuit.ie/news/look-back-with-thanks/ (accessed August 3, 2020).

${ }^{24}$ Some of the photographic studios used for this purpose include: Studio, Valetta, Malta; in London, H. Barraud, the Claudet Studio, the London Stereoscopic and Photographic Company, and Adolphus Wing; James Harrison, 172 Woodhouse Lanes, Leeds, England; in Sydney, Australia: Freeman and Company Limited, J. Roarty Studio, and Talma; in Melbourne, Australia: J. W. Lindt and A. McDonald; Arthur Green, Port Elizabeth, South Africa; Gilles, 4 rue de la Croix, Namur, Belgium; in Rome, Borelli and G. Fellici; in France, L. Krier, Metz.

${ }^{25}$ Orla Fitzpatrick, "Mondays at the Mess: Momento mori: Post-mortem Photography \& Child Mortality in Early C20th Dublin," May 14, 2018; http://www.richmondbarracks.ie/messtalks/momento-mori-post-mortem-photography-child-mortality-early-20th-century-dublin/ (accessed Aug-ust 3, 2020).
} 
twenty years later, radically re-contextualizing their meaning." 26 Assisted by financial access to purse this leisure pursuit, Irish Jesuits who photographed, as opposed to paying a studio, regarded it as a hobby whose best exponents were used for promotional purposes in Jesuit works. A simplified Jesuit photographic categorization would consist of hobby (records of Jesuit life and publications), education (colleges and science), and evangelization (missions). Photographs became part of the Irish Jesuits' material culture, to be handled and shared, and to be seen on the walls of residences and schools.

\section{Irish Jesuit Colleges}

Experimentation with photographic practices occurred in Jesuit colleges worldwide, from St. Ignatius Mission, Montana, United States, to Mungret College, Limerick, Ireland. ${ }^{27}$ Jesuit college journals at Mungret (The Mungret Annual [1898-1974]), Sacred Heart College, Limerick (The Crescent Review [18981900]), Belvedere College, Dublin (The Belvederian [1906-]), Clongowes Wood College, Kildare (The Clongownian [1895-]), and St. Ignatius College, Galway (The Ignatian [1906]) used photography to depict activities such as excursions (especially pilgrimages or religious processions), theatricals, news features, obituaries, sodalities, and sports. Acting as a physical and financial recruiter, photographs portrayed all that was positive in the respective Jesuit educational establishments. At the turn of the twentieth century, the availability of small, portable, and cheaper cameras made it possible for the creation of camera clubs (often aligned with the cycling club). At Belvedere College, Browne re-founded the camera club upon his return as a teacher in 1906, and

Mr Lafayette kindly consented to send an experienced photographer to Belvedere on certain days to give lectures on the camera and its management [...] the lectures were always well attended and often in the corridors of College one might see boys, young and old, perusing photographic pricelists, aids to photography and the like. ${ }^{28}$

\footnotetext{
${ }^{26}$ John Berger, Jean Mohr, and Nicolas Philibert, Another Way of Telling: A Possible Theory of Photography (London: Bloomsbury, 2016), 128.

${ }^{27}$ Peter Costello (Clongowes Wood: A History of Clongowes Wood College 1814-1989 [Dublin: Gill and Macmillan, 1989], 134) mentions "the existence of photographic equipment at Clongowes from the early $1850 \mathrm{~s}[\ldots]$ the college had both daguerreotype and wet plate collodion plate cameras."

${ }^{28}$ Vincent J. O’Hare, “The Photographic Club,” The Belvederian (1907): 124-25, here 124.
} 
Photography was in the Browne family-Frank's brother, Robert (1876-1938), accompanied their uncle, the bishop of Cloyne, on a trip to the United States and acted as the unofficial photographer. On Robert's return, Frank requested that he give a limelight lecture to the pupils of Belvedere. ${ }^{29}$

The most famous Irish Jesuit alumnus, James Joyce (1882-1941), attended Belvedere and University College, Dublin, as did Browne. ${ }^{30}$ Both would have experienced photography at annual college events. ${ }^{31}$ According to Bruce Bradley, S.J., Joyce would also have learned of various photographic practices at Clongowes Wood College (1888-91) through his admiration of fellow student Dominic Kelly (1873-1952), a photographic experimenter. ${ }^{32}$ Kelly allied his photographic skills with singing and cycling at Clongowes, as the "newly introduced cycle-track (the 'cinder path' on which Stephen Dedalus came to grief and broke his glasses, when struck by one of the cyclists) had recently been laid down about this time." ${ }^{33} \mathrm{Re}$ turning to teach there in 1914, Kelly, now a Jesuit, "perhaps to mark the college's centenary year $[. .$.$] took a new step by performing the remarkable feat of putting a$ camera on a timer in a kite and floating it above the buildings to take the first ever aerial photograph." 34 Irish society has been described as not as literate visually as we are verbally, but in Grace, a short story in Dubliners (1914), Joyce allows Martin Cunningham to (mis-)remember Ars Photographies (On photography), a poem written in praise of photography by Cardinal Pecci in 1867, later to become Pope Leo XIII (r.1878-1903): ${ }^{35}$

"I remember reading," said Mr Cunningham, "that one of Pope Leo's poems was on the invention of the photograph - in Latin, of course."

"On the photograph!" exclaimed Mr Kernan.

"Yes," said Mr Cunningham.

He also drank from his glass.

"Well, you know," said Mr M'Coy, "isn't the photograph wonderful when you come to think of it?"

\footnotetext{
${ }^{29}$ This is featured as "Through America with Cardinal Logue," The Belvederian (1909): 142-43.

${ }^{30}$ In 1883, the trustees of the Catholic University leased to the Jesuits the university buildings of 84-86 St. Stephen's Green, which were given the new name of University College, Dublin. Until 1909, the Jesuits ran University College, Dublin.

${ }^{31}$ James Joyce is featured in a photograph, facing page 328, in Lambert McKenna, A Page of Irish History: Story of University College, Dublin 1883-1909 (Dublin: Talbot Press, 1930).

${ }^{32}$ Bruce Bradley, S.J., "Dominic Kelly: The Boy Who Sang for (James) Joyce," Coiseanna: The Journal of Clane Local History Group 6 (April 2017): 52-70, here 63. Clongowes Wood College is a boarding school for boys. Founded in 1814, it is located in County Kildare.

${ }^{33}$ Draft copy of Bruce Bradley, S.J., "Dominic Kelly: The Boy Who Sang for (James) Joyce," April 3, 2017, IE IJA/CLON, footnote 12.

${ }^{34}$ Bradley, "Dominic Kelly," 68.

${ }^{35}$ Lelia Doolan, "A Debate on Media and Popular Culture," Crane Bag 8, no. 2 (1984): 175-95. Terence Brown, "Joyce's Magic Lantern,” James Joyce Quarterly 28, no. 4, papers from the Joyce and History Conference at Yale, October 1990 (Summer 1991): 791-98, here 791.
} 
"O, of course," said Mr Power, "great minds can see things."

"As the poet says: Great minds are very near to madness," said $\mathrm{Mr}$ Fogarty. ${ }^{36}$

Furthermore, in Eveline (1904), Joyce uses photography to explore memory and remembrance:

And yet during all those years she had never found out the name of the priest whose yellowing photograph hung on the wall above the broken harmonium beside the coloured print of the promises made to Blessed Margaret Mary Alacoque. He had been a school friend of her father. Whenever he showed the photograph to a visitor her father used to pass it with a casual word:

"He is in Melbourne now." 37

In The Mungret Annual, photography was used as a communications tool for their alumni, prospective students (and their parents), and benefactors. ${ }^{38}$ The annual depicted successful past pupils with photographic portraits, exemplars of which included those training as priests and those just ordained. ${ }^{39}$ The photographs returned by Mungret religious alumni from the United States, Australia, Ceylon, China, Cuba, Germany, Italy, South Africa, and Syria show the geographic diversity of the college, and act, in a missionary sense, as clerical travelogue advertisements. Jesuits John Egan (1875-1938), the aforementioned Kelly, and William O'Leary (1869-1939) encouraged the students to photograph, especially on outings to nearby attractions such as Bunratty, Lough Gur, and the Shannon at Mungret, to evoke a sense of place and visually record aspects of Mungret life. Jesuits who gave visiting lectures made their presentations multimedia by supplying lithographed syllabus of the points outlined, with "magic lantern entertainments." ${ }^{\circ 0}$ By 1907, interest in photography within the college compelled the editor to start a competition and offer a bound volume of the annual for the best

\footnotetext{
${ }^{36}$ James Joyce, Dubliners (London: Penguin, 1964), 165-66.

${ }^{37}$ Joyce, Dubliners, 35. For further Joycean photographic connections, see Georgina Elaine Binnie, "James Joyce and Photography" (PhD diss., University of Leeds, 2016), and Orla Fitzpatrick, https://jacolette.wordpress.com/tag/james-joyce-and-photography/ (accessed August 3, 2020).

${ }^{38}$ Mungret College was a Jesuit apostolic school and a lay secondary school (1882-1974). For more information, see Thomas Morrissey, S.J., William Ronan, S.J., 1825-1907: War Chaplain, Missioner, and Founder of Mungret College (Dublin: Messenger Publications, 2002), and Kevin A. Laheen, S.J., The Jesuits in Mungret: Book One; Monastery to College 1882-1974 (Limerick: O’Brien Photo Books, 2014).

${ }^{39}$ Photographs were sent back by alumni on their travels to the college, with specific references to religious sites: "Oostaker: The Loudres of Flanders," The Mungret Annual (1898): 26; "The Basilica of the Sacred Heart, Montmartre," The Mungret Annual (1899): 46.

${ }^{40}$ On St. Stephen's Night, 1905, Joseph McDonnell, S.J. (1858-1928) gave a magic lantern entertainment on the Russo-Japanese war. The Mungret Annual (1906): 61.
} 
original photographs: "The set should contain at least three pictures of a good standard of excellence from a photographic as well as an artistic standpoint." ${ }^{41}$

Photography developed alongside Jesuits' individual interests. The Irish Jesuit scientist Henry Gill (1872-1945) won a competition in Badminton Magazine for his photographic composition of the hunt at Clongowes in 1903; he later gave a lecture entitled "The Effect of a Low Potential Electric Current on Photographic Plates." 42

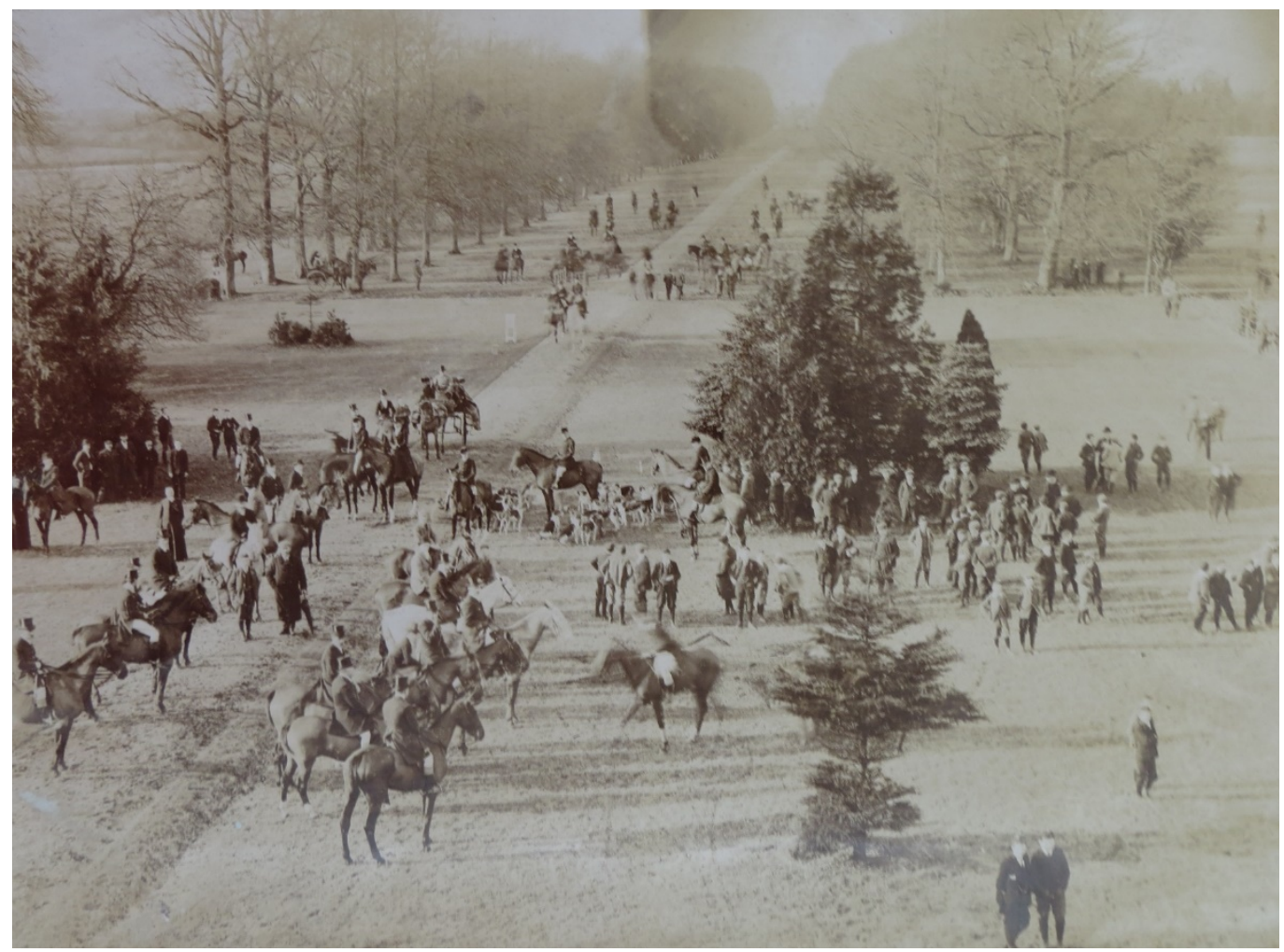

Figure 2. The Hunt at Clongowes Wood College. County Kildare, 1903. IE IJA/J17/33.

Edward F. Pigot (1858-1929), an Irish Jesuit, astronomer, and seismologist, wrote about "a photographic Foucault pendulum" in 1916, having previously opened the Riverview College Observatory, Sydney, Australia. ${ }^{43}$ John MacErlean (18701950), an Irish Jesuit historian and archivist, researched material on the cause of the Irish martyrs in Exaten, Holland. Aware that he would also come across the

${ }^{41}$ The Mungret Annual (1907): 5.

${ }^{42}$ Henry Gill lecture to the Royal Dublin Society, Dublin, Ireland, in May 1913. During the First World War, Gill kept a diary containing over 150 photographs while serving as a military chaplain. See IE IJA/CHP1/29 and Damien Burke, ed., Irish Jesuit Chaplains in the First World War (Dublin: Messenger Publications, 2014). Across the Atlantic, Brosnan shared his photographic expertise through articles in the Bulletin of the American Association of Jesuit Scientists (Eastern Section), searchable on https://jesuitonlinelibrary.bc.edu/ (accessed August 3, 2020).

${ }^{43}$ William O'Leary succeeded Pigot at Riverview observatory, having established Ireland's first seismograph at Mungret College (c.1909) and the camera club there. 
history of the Irish province, MacErlean used photography to supplement transcriptions and suggested to his provincial that Browne, who at this time was working as a military chaplain in Germany, help in photographing material. ${ }^{44}$ The Irish Jesuit John Ryan (1894-1973) arrived as a photographic assistant in July 1920 and "has now become an expert in photographing manuscripts, he has done all needed for the Process de Scriptis, and all Litterae Annuae that are extant which makes some hundred photographs." 45

The emergence of the Irish Jesuit mission to Hong Kong (1926) and Northern Rhodesia (1946) increased overseas photographic endeavors to inform, for use in publications, and for the hobby photographer. ${ }^{46}$ Indeed, Irish Jesuit Tom Martin's (1907-78) Hong Kong camera work was enough to get the gentlest of slaps on the wrists from his Irish provincial: "You know, I suppose, that it is forbidden to Ours by Very Rev. Fr General [Wlodimir Ledóchowski (in office 1915-42)] to have or use a camera for private purposes; hence during your Theology you are not to have or use a camera without leave toties quoties from the Rector." 47

\footnotetext{
${ }^{44}$ Letter from John MacErlean to Thomas V. Nolan, May 1, 1920, IJA/ADMN/13/127. Elizabeth Mullins, "Fr. John MacErlean, S.J., and the Development of the Irish Jesuit Archive," in Archives and Archivists, ed. Ailsa C. Holland and Kate Manning (Dublin: Four Courts, 2006), 166-76, here 171.

${ }^{45}$ Letter from John MacErlean to Thomas V. Nolan, August 10, 1920, IJA/ADMN/13/127; Mullins, "Fr. John MacErlean, S.J., and the Development of the Irish Jesuit Archive," 171.

${ }^{46}$ Jesuit photographers include Gerard Casey, James Dunne, Joseph Garland, Hogan, Francis Keenan, Joseph McAsey, Tom Martin, Henry O'Brien, Walter O'Connor, and Robert Kelly.

${ }^{47}$ Letter from Laurence Kieran to Thomas Martin, September 3, 1936, IE IJA/J243/3.
} 


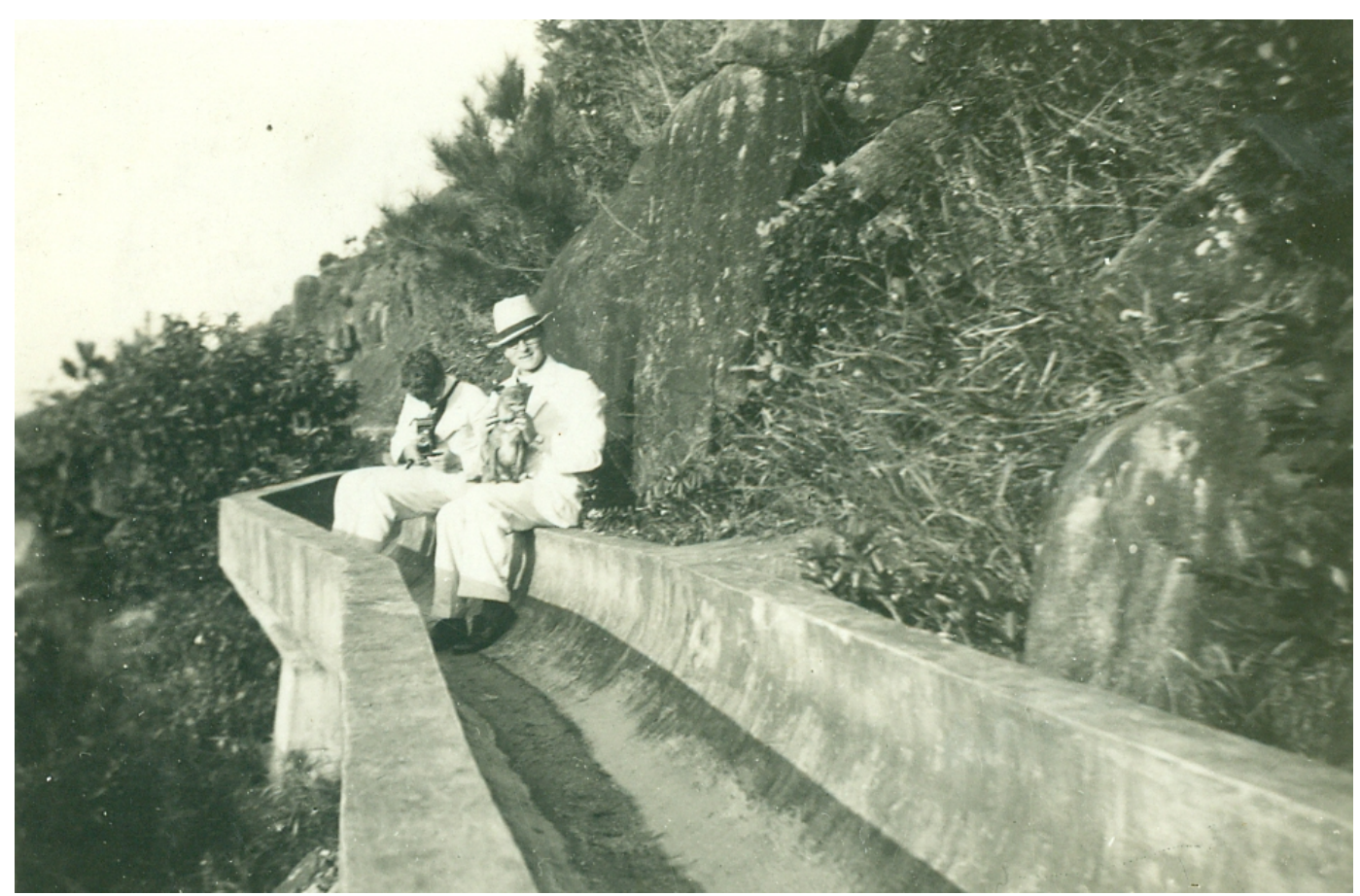

Figure 3. Fr. Gerald 'Doc' Kennedy, dog and self (Thomas Martin). Hong Kong, c.1936. IE IJA/MSSN/HONGP/48.

Irish Jesuit publications such as the Irish Jesuit Directory (1928-79), and to a lesser extent, the Sacred Heart Messenger (1888-), featured photographs of Irish Catholic missionaries as an aid to articles and also to fundraise. Throughout the twentieth century, Irish Jesuits created photographic albums, mainly of Jesuit life, and especially of holiday "villas." There was no ethical hesitation to take or not take a photograph, as these photographs were "For Ours Only." ${ }^{48}$ Irish Jesuits, such as Donal O'Sullivan (1904-77) and Cyril (Denis) Barrett (1925-2003), were actively involved in promoting the visual arts. ${ }^{49}$ By the 1960 s, certain Irish Jesuits were trained in aspects of the media, and the establishment of a communication center was proposed.

\section{The IJA}

The IJA contains the records of the Society of Jesus in Ireland, with documents dating from 1577. Its location, in a nineteenth-century Georgian building in Dublin, was redeveloped in 1997, doubling in size, with air conditioning and dehumidifier,

\footnotetext{
${ }^{48}$ Berger, Mohr, and Philibert, Another Way of Telling, 80.

${ }^{49}$ O'Sullivan was appointed to the Arts Council of Ireland in 1956 and served as the body's director (1960-73), and Barrett was an art critic and curator.
} 
controlling temperature and humidity. ${ }^{50}$ It is a shared space: a Jesuit residence runs throughout the building, while the archives are self-contained in the basement, albeit without separate storage for Jesuit photographs, papers, and ephemera. ${ }^{51}$ Photographs are stored in traditional (printed out) and digital formats: the former, consisting of glass plate, albumen prints, carte-de-visite, cabinet cards, negatives (cellulose nitrate and cellulose acetate), and portrait postcards; the latter, JPEGS and TIFFS. ${ }^{52}$ Separated into collections, such as Irish Jesuit colleges, residences, missions, and administration, photographs are also embedded in over eight hundred deceased Jesuit "papers of the holy, the controversial, the academic and the blessedly ordinary." 53 This fits with the creation of individual files for deceased Jesuits, taking its cue from previous Jesuit archival norms. ${ }^{54}$ For preservation and access purposes, where appropriate, photographic material has been removed from its original housing and placed in archival standard storage.

Photographs are compromised by interaction with the archival processes of acquisition, appraisal, and cataloging. The IJA acquisition policy for deceased Irish Jesuit papers references photographs, as does Practica quaedam: Norms for Correspondence with Father General and Other Concrete Business Matters. However, policies at a hierarchical level, such as Practica quaedam and Practical Proposal Regarding Archives of Provinces, Houses, and Apostolic Works are not self-regulatory, and operate at a level that does not reflect the everyday work of the photographic archives - digital photography, social media, the right to be forgotten, and the consent of those photographed and the photographer. ${ }^{55}$ Acquisition of photographic material by the province archivist mainly occurs after a Jesuit's death or

\footnotetext{
${ }^{50}$ See Fergus O'Donoghue, S.J., "The Development of the Irish Jesuit Archives until Spring 2001," in Scriptis tradere et fideliter conservare: Archives as "Places of Memory" within the Society of Jesus, ed. Thomas M. McCoog (Rome: Jesuit General Curia, 2003), 140-42.

${ }^{51}$ Since 1997, the Irish province of the Society of Jesus has employed professionally qualified archivists at the IJA.

52 JPEG (Joint Photographic Experts Group) is a standard image format, and TIFF (Tagged Image File Format) is a file format for storing raster graphics images. While TIFF is a preferred format for preservation, JPEG is also acceptable. In the near future, a survey will determine the quantity (roughly fifty thousand photographs), variety of photographic formats, and condition of the photographic collection at the IJA.

${ }_{53}$ O'Donoghue, "Development of the Irish Jesuit Archives," 143.

${ }^{54}$ Fergus O’Donoghue, S.J., "Irish Jesuit Archives," Archivium Hibernicum 41 (1986): 64-66; Stephen Redmond, S.J., "A Guide to the Irish Jesuit Province Archives," Archivium Hibernicum 50 (1996): 127-31; Jesuits, Practica quaedam: Norms for Correspondence with Father General and Other Concrete Business Matters (Rome: Jesuit General Curia, 2019); Thomas M. McCoog, A Guide to Jesuit Archives (St. Louis, MO: Institute of Jesuit Sources, 2001); McCoog, Scriptis tradere et fideliter conservare; Damien Burke, "Deceased Jesuit Papers," Dublin, 2016, 1—document given to Irish Jesuit superiors in January 2016.

${ }^{55}$ Burke, "Deceased Jesuit Papers," 1; Jesuits, Practica quaedam, 6; Peter-Hans Kolvenbach, S.J. ("Practical Proposals Regarding Archives of Provinces, Houses, and Apostolic Works," Acta Romana 23 [2003]: 378-92, here 391) refers to "Documents Important for History: $3^{\circ}$ Photographs and other graphic documents of the house or work and significant events related with them."
} 
the closure of a Jesuit work, which leaves scope for lacunae. Positively, the IJA acquisition policy does inform the archivist to be cognizant of what photographic material to look out for; however, decision-making is often based on what was previously acquired and discussions with individual works, such as the communications office, and individual Jesuits. ${ }^{56}$

If the acquisition of photographic material is blurred, appraisal is biased, relying on factors such as date, format, photographer, and what the photograph depicts. The archivist prioritizes material that reflects Jesuit ways of working, such as Jesuit formation, villas, and missions, with personal family photographs of less consequence. This appraisal requires knowledge of the culture and language of the Society of Jesus in order to comprehend what best represents the Jesuit photographic record. In appraising, archivists are trained to be aware of assigning significance to photographs based on their own personal interests and background. ${ }^{57}$ It is worth noting that every archival decision made is informed by organizational, social, and personal interests, and by documenting these decisions, at the very least, the IJA can reflect on and communicate that "archives are not neutral: they embody power inherent in accumulation, collection, and hoarding." 58

In cataloging, the IJA takes care in describing photographs, as text gives authority and authenticity to the visual, and language can determine issues of accessibility, understanding, and usage. ${ }^{59}$ The photograph taken by the Irish Jesuit Walter O'Connor (1910-67) of a wedding in Northern Rhodesia highlights how captions place a photograph in context and the combination of photographs with words produces an effect of certainty.

\footnotetext{
${ }^{56}$ Some photographs at the IJA are without captions. The archivist takes an educated guess of the date, location, and what the photograph contains. The benefit of the IJA location means that the identification of photographs is helped by Jesuits who live at St. Ignatius House of Writers, Lower Leeson Street, Dublin. This is a project that could be further developed.

${ }^{57}$ Archivists who have a professional qualification recognized by the Archives and Records Association, UK and Ireland, adhere to a code of ethics (May 9, 2018), 3; https://www.archives.org.uk/membership/code-of-ethics.html (accessed August 3, 2020).

${ }^{58}$ Allan Sekula, "Reading an Archive: Photography between Labour and Capital," in The Photography Reader, ed. Liz Wills (London: Routledge, 2003), 443-52, here 446.

${ }^{59}$ The cataloging of photographic material at the IJA has unsatisfactorily drifted between Microsoft Office software and the proprietary archival software, Adlib, with no online access. In 2020, the IJA will commence a project using AtoM in order to make the archival descriptions more open and transparent and reduce accessibility barriers for internal and external researchers. AtoM (Access to Memory) is a web-based, open source application for standards-based archival description. See Lisa Shortall, "200 years at Tullabeg" (Jesuits in Ireland, April 9, 2019); https://www.jesuit.ie/news/200years-at-tullabeg/ (accessed August 3, 2020). See also SEPIADES. Recommendations for cataloging photographic collections, International Council on Archives (Amsterdam, 2003); https://www.ica.org/en/sepiades-recommendations-cataloguing-photographic-collections (accessed August 3, 2020).
} 


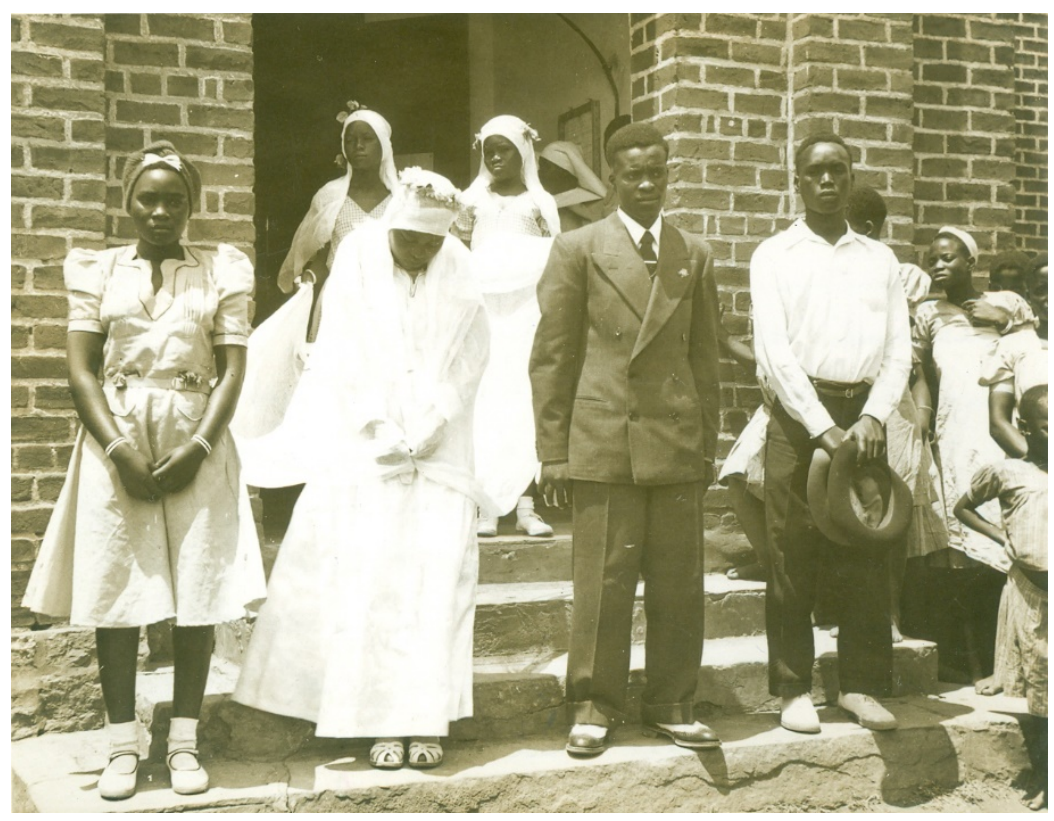

Figure 4. Wedding in Chikuni. Northern Rhodesia, March 1951. IE IJA/MSSN/ZAMP/174.

In the photograph, the bride's expression gives the impression that she may be reticent, sorrowful, or is asserting agency, by perhaps denying the gaze of the missionary's camera. ${ }^{60}$ In fact, O'Connor explains the local tradition with a caption on the reverse: "Notice that the Bride refused to face me-the photographer! not that she feared to break my camera. No, the African custom is that the Bride should be as sad + demure as possible on her wedding day." $" 61$

\section{Digital Photography}

The accumulation of born-digital photographs from hardware (laptops, desktop computers, tablets, smartphones, and memory sticks) and virtual sources (cloud devices and social media accounts) presents the IJA with new challenges. The sudden death of an Irish Jesuit in 2018 raised the specter of a future digital dark-age if we do not engage and collaborate to preserve the digital footprint of the Society of Jesus. This Jesuit lived his life digitally, with no physical diary, writings, or passwords. His laptop, smartphone, and tablet were accessible only through his fingerprint passcode.

\footnotetext{
${ }^{60}$ Kyle Jackson, "Hearing Images, Tasting Pictures: Making Sense of Christian Mission Photography in the Lushai Hills District, Northeast India (1870-1920)," in From Dust to Digital: Ten Years of the Endangered Archives Programme, ed. Maja Kominko (Cambridge: Open Book Publishers, 2015), 445-85, here 477.

${ }^{61}$ Zambian mission papers: IE IJA/MSSN/ZAMP/174.
} 
Use of archives has not changed - in 1919, MacErlean used photography to speed up his archival research at Exaten, and in the present day, archival users have smartphones to capture primary source material. ${ }^{62}$ The IJA has digitized photographs on a case-by-case basis to answer researchers' and internal Jesuit queries, and to promote archival events on social media. ${ }^{63}$ Caution should be noted, as by digitizing, the features of a photograph that were once "three- or two-dimensional physical objects become one-dimensional and intangible surrogates." ${ }^{\text {"64 }}$ Furthermore, the archival impulse to create order by digitizing may in fact skew the contexts that "originate from the materiality of the original photographic object." 65 The IJA is investigating how to decolonize the archives by making available the photographic material it holds on Hong Kong and Zambia in an equal, accessible way that respects the fidelity of the photograph.

Digitization, however, is not the same as digital preservation, and solutions to the digital deluge of the twentieth-first century are not as simple as just uploading material to the cloud. Taking an extreme hypothetical example: imagine a meeting between Pierre Favre and Ignatius in Paris in the present day. Texting by real-time messaging service, they agree to meet, using a photograph of the church at Montmartre to communicate their location. If this electronic communication was available for digital preservation, would there not be a clamor to preserve it? How do we ensure that we have similar quality archival sources from today as we do from centuries past? Harking back to a pre-digital age, using the same archival processes does not suffice, as "digital information lasts forever, or five yearswhichever comes first." ${ }^{\prime 66}$ Preservation of digitized and born-digital photographs is an ongoing, long-term process. ${ }^{67}$

\footnotetext{
${ }^{62}$ The IJA allows digital cameras and smartphones for certain material. There are positives in terms of efficiency and convenience in allowing digital cameras but also implications such as digital preservation, copyright, and shareability, which require teasing out.

${ }_{63}$ IJA on Flickr: https://www.flickr.com/photos/jesuitsireland/collections/72157622161762485/ and Twitter: https://twitter.com/sjarchives (accessed August 3, 2020).

${ }^{64}$ Sassoon, "Photographic Meaning in the Age of Digital Reproduction," 310.

${ }^{65}$ Sassoon, "Photographic Meaning in the Age of Digital Reproduction," 311.

${ }^{66}$ Jeff Rothenberg, RAND Video V-079 (1997). Ensuring the Longevity of Digital Information (Revision 1999); https://www.clir.org/wp-content/uploads/sites/6/ensuring.pdf (accessed August 3, 2020).

${ }^{67}$ The IJA joined the Digital Repository of Ireland (DRI) in 2019 as an institutional member. The DRI is a trusted national infrastructure for Ireland's social and cultural heritage; https://www.dri.ie/ (accessed August 3, 2020); Sara Day Thomson, "Save Your Social Media," April 12, 2019; https://www.dpconline.org/blog/save-your-social-media and "Personal Archiving: Preserving Your Digital Memories"; http://digitalpreservation.gov/personalarchiving/photos.html (accessed August 3, 2020).
} 


\section{Conclusion}

Irish Jesuit photography both pre- and post-dates the prolific Jesuit Browne, and this article has attempted to chronicle its development at the IJA. I have endeavored to evaluate the implications of the archival processes of acquisition, appraisal, and description on traditional and born-digital photography. Photography, as a historical source, appearing in college annuals or Jesuit holiday snaps, has an intrinsic value. In addition, it has a pastoral function in today's Jesuit mission, with scope for creativity. ${ }^{68} \mathrm{~A}$ balance is required in making photographic material accessible and respecting confidentiality, consent, copyright, and preservation. Social media has changed the way we photograph and what we photograph; the days of sepiatoned family photographs are a thing of the past, given that we rarely print out the thousands of photographs stored on our digital devices.

Archival endeavors have, in the past, been "carried out in silence and far from clamour"; however, advocacy is required to highlight that photographic archives are not neutral, and biases exist. ${ }^{69}$ Jesuit archivists should actively question how the poor and powerless are represented in the archives, and the role we can "play in both advocating for and practicing environmentally sustainable digital preservation."70 The Society's ongoing commitment to the development and preservation of archives is commendable. The connected histories that photography represents for the Society of Jesus should be shared. ${ }^{71}$

\footnotetext{
${ }^{68}$ The Jesuit in Britain province provided a platform where positive images of refugees can be promoted in order to create a culture of welcome throughout the UK. "Refugees behind the Camera," June 16, 2004. https://www.jesuit.org.uk/blog/refugees-behind-camera (accessed August 3, 2020). "Can photographic Archives Play a Role in the Society's Universal Apostolic Preferences?"; https://jesuits.global/en/uap (accessed August 3, 2020).

${ }^{69}$ Address of Pope Francis (r.2013-) to officials of the Vatican Secret Archive, Clementine Hall, Rome, Italy (March 4, 2019); http://w2.vatican.va/content/francesco/en/speeches/2019/march/documents/papa-francesco_20190304_archivio-segretovaticano.htm (accessed August 3, 2020).

${ }^{70}$ Keith L. Pendergrass et al., "Toward Environmentally Sustainable Digital Preservation," American Archivist, 82, no. 1 (2019): 165-206, here 195. Issues of archival power have been widely discussed by archivists such as Michelle Caswell, Terry Cook, Jarrett M. Drake, Verne Harris, and Howard Zinn.

${ }^{71}$ The superior general of the Society of Jesus, Adolfo Nicolás (in office 2008-16), stated that "it is certainly gratifying, humbling and encouraging that so many people who are not Jesuits take advantage of our archives and study the Society's past" in "Organization of the Archivum Romanum Societatis Jesu [ARSI]” (2010/4), Acta Romana Societatis Iesu 24 (2010): 931-33, here 932.
} 